CANON

FODDER 



\section{CANON FODDER}

HISTORICAL

WOMEN

POLITICAL

THINKERS

PENNY A, WEISS

THE PENNSYLVANIA STATE UNIVERSITY PRESS

UNIVERSITY PARK, PENNSYLVANIA 
Weiss, Penny A.

Canon fodder : historical women political thinkers / Penny A. Weiss.

p. $\mathrm{cm}$.

Includes bibliographical references and index. Summary: "A discussion of women thinkers in political philosophy, and the nature of political inquiry" — Provided by publisher.

ISBN 978-0-27I-03519-2 (cloth : alk. paper)

I. Women political scientists.

2. Women political scientists - History.

3. Feminism-Political aspects.

I. Title.

$\mathrm{JA}_{92 .} \mathrm{W}_{45} 2009$

$320.092 ' 2-\mathrm{dc} 22$

200900098I

Copyright (C) 2009 The Pennsylvania State University All rights reserved

Printed in the United States of America

Published by The Pennsylvania State University Press, University Park, PA I6802-I003

It is the policy of The Pennsylvania State University Press to use acid-free paper. This book is printed on Natures Natural, containing $50 \%$ post-consumer waste, and meets the minimum requirements of American National Standard for Information Sciences-Permanence of Paper for Printed Library Material, ANSI Z39.48-1992. 
To BERENICE CARROLL, whose light has inspired many.

With love, admiration, and gratitude. 
